\title{
Letter
}

\section{Prorocentin, a New Polyketide from the Marine Dinoflagellate Prorocentrum lima}

Chung-Kuang Lu, Hong-Nong Chou, Ching-Kuo Lee, and Tzong-Huei Lee

Org. Lett., 2005, 7 (18), 3893-3896• DOI: 10.1021/ol051300u • Publication Date (Web): 02 August 2005

Downloaded from http://pubs.acs.org on May 8, 2009

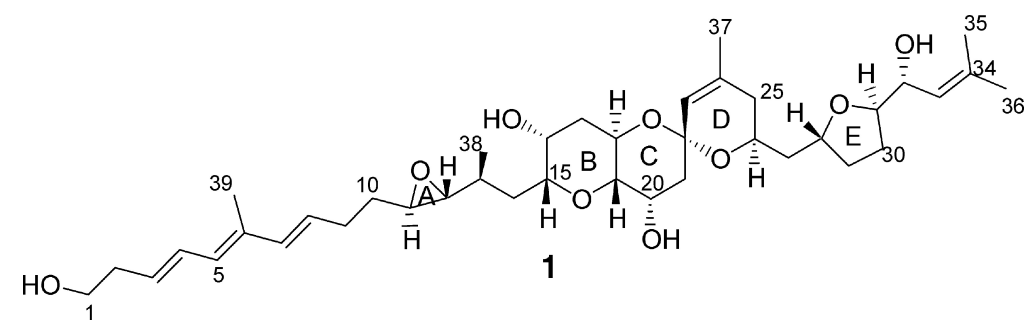

\section{More About This Article}

Additional resources and features associated with this article are available within the HTML version:

- $\quad$ Supporting Information

- Links to the 1 articles that cite this article, as of the time of this article download

- $\quad$ Access to high resolution figures

- $\quad$ Links to articles and content related to this article

- $\quad$ Copyright permission to reproduce figures and/or text from this article

\section{View the Full Text HTML}




\title{
Prorocentin, a New Polyketide from the Marine Dinoflagellate Prorocentrum lima
}

\author{
Chung-Kuang Lu, ${ }^{*,+, \ddagger}$ Hong-Nong Chou, ${ }^{\S}$ Ching-Kuo Lee, ${ }^{\perp}$ and Tzong-Huei Lee ${ }^{\perp}$ \\ National Museum of Marine Biology and Aquarium, Pingtung 944, Taiwan, Institute of \\ Marine Biotechnology, National Dong Hwa University, Pingtung 944, Taiwan, Institute \\ of Fisheries Science, National Taiwan University, Taipei, 106, Taiwan, and Graduate \\ Institute of Pharmacognosy, Taipei Medical University, Taipei, 110, Taiwan
}

cklu@nmmba.gov.tw

Received June 3, 2005

\section{ABSTRACT}

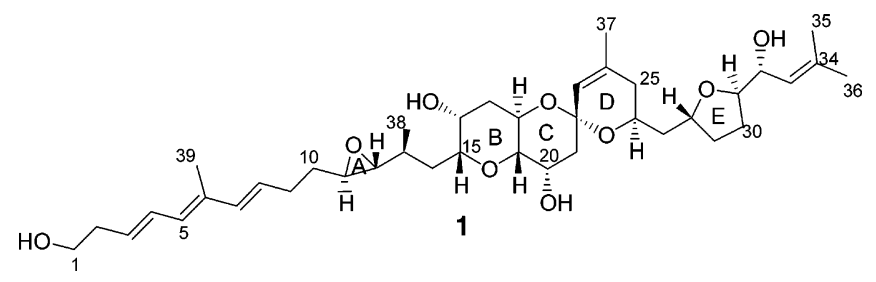

Prorocentin (1), isolated from an okadaic acid-producing organism, Prorocentrum lima, possessed all-trans trienes, an epoxide, as well as the 6/6/6-trans-fused/spiro-linked polyether ring moieties. The unique structure supports the proposed cyclization mechanism, polyene formation, epoxidation, and cyclization, of marine polyether toxins. The relative stereostructure was determined on the basis of spectral data.

Marine dinoflagellates of the genus Prorocentrum have been reported to produce novel bioactive secondary metabolites of entirely different skeletons such as linear polyether toxins ${ }^{1}$ and macrolides. ${ }^{2}$ Okadaic acid and its analogues are some of the most attractive substances in marine natural products chemistry. ${ }^{1}$ In particular, okadaic acid has been shown to be a highly selective inhibitor of protien phosphatases, ${ }^{3}$ to be mainly responsible for diarrhetic shellfish poisoning, ${ }^{4}$ and

\footnotetext{
National Museum of Marine Biology and Aquarium.

National Dong Hwa University.

$\S$ National Taiwan University.

${ }^{\perp}$ Taipei Medical University.

(1) (a) Murakami, Y.; Oshima, Y.; Yasumoto, T. Bull. Jpn. Soc. Sci. Fish. 1982, 48, 69-72. (b) Hu, T.; Marr, J.; Anthony, S. W.; Quilliam, M. A.; Walter, J. A.; Wright, J. L. C.; Pleasance S. J. Nat. Prod. 1992, 55, 1631-1637. (c) Hu, T.; Curtis, J. M.; Walter, J. A.; Wright, J. L. C. J. Chem. Soc., Chem. Commun. 1995, 597-599. (d) Suarez-Gomez, B.; Souto, M. L.; Norte, M.; Fernandez, J. J. J. Nat. Prod. 2001, 64, 1363-1364. (e) Fernandez, J. J.; Suarez-Gomez, B.; Souto, M. L.; Norte, M. J. Nat. Prod.
} 2003, 66, 1294-1296.

(2) (a) Torigoe, K.; Murata, M.; Yasumoto, T. J. Am. Chem. Soc. 1988, 110, 7876-7877. (b) Hu, T.; Curtis, J. M.; Walter, J. A.; Wright, J. L. C. Tetrahedron Lett. 1999, 40, 3977-3980. (c) Lu, C.-K.; Lee, G.-H.; Hwang R.; Chou, H.-N. Tetrahedron Lett. 2001, 42, 1713-1716.

(3) Takai, A.; Bialojan, C.; Troschka, J.; Ruegg, J. C. FEBS Lett. 1987, $217,81-84$

(4) Yasumoto, T.; Oshima, Y.; Sugawara, W.; Fukuyo, Y.; Oguri, H.; Igarashi, T.; Fujita, N. Bull. Jpn. Soc. Sci. Fish. 1980, 46, 1405-1411. to be biosynthesized via an unusual route involving both the carbon backbone formation ${ }^{5}$ and the cyclization mechanism. ${ }^{6}$ This irregularity of the carbon backbone synthesis has also been reported in other marine dinoflagellate polyketides, e.g., brevetoxins, ${ }^{7}$ goniodomin A, ${ }^{7}$ amphidinolides, ${ }^{7}$ yessotoxins, ${ }^{8}$ and amphidinols. ${ }^{9}$ Among those, only the okadaic acid skeleton and brevetoxins went through the cyclization mechanism to form spiro-linked and/or trans-fused polyether

(5) (a) Yasumoto, T.; Torigoe, K. J. Nat. Prod. 1991, 54, 1486. (b) Norte, M.; Padilla, A.; Fernandez, J. J.; Souto, M. L. Tetrahedron 1994, 50, 91759180. (c) Needham, J.; Hu, T.; McLachlan, J. L.; Walter, J. A.; Wright, J. L. C. J. Chem. Soc., Chem. Commun. 1995, 1623-1624. (d) Wright, J. L. C.; Hu, T.; McLachlan, J. L.; Needham, J.; Walter, J. A.; J. Am. Chem. Soc. 1996, 118, 8757-8758. (e) Macpherson, G. R.; Burton, I. W.; LeBlanc, P.; Walter, J. A.; Wright, J. L. C. J. Org. Chem. 2003, 68, 1659-1664. (f) Daranas, A. H.; Fernandez, J. J.; Norte, M.; Gavin, J. A.; Suarez-Gomez, B.; Souto, M. L. Chem. Rec. 2004, 4, 1-9.

(6) (a) Murata, M.; Izumikawa, M.; Tachibana, K.; Fujita, T.; Naoki, H. J. Am. Chem. Soc. 1998, 120, 147-151. (b) Izumikawa, M.; Murata, M.; Tachibana, K.; Fujita, T.; Naoki, H. Eur. J. Biochem. 2000, 267, 51795183.

(7) (a) Moore, B. S. Nat. Prod. Rep. 1999, 16, 653-674. (b) Rawlings, B. J. Nat. Prod. Rep. 1999, 16, 425-484. (c) Shimizu, Y. Curr. Opin. Microbiol. 2003, 6, 236-243.

(8) Satake, M. Tennen Yuki Kagoubutsu Toronkai Yoshishu 2000, 42, $259-264$

(9) Houdai, T.; Matsuoka, S.; Murata, M.; Satake, M.; Ota, S.; Oshima, T.; Rhodes, L. L. Tetrahedron 2001, 57, 5551-5555. 
rings. The enzyme-mediated epoxidation at the double bonds, followed by nucleophilic addition upon cyclization, were suggested as the mechanisms of formation of ether rings. ${ }^{6,7 \mathrm{c}}$ However, none of the natural products bearing the serial functional groups of cyclization cascade had been isolated from dinoflagellates. In our project, searching for new biologically active substances from marine microalgae, we isolated prorocentin (1) from the okadaic acid-producing organism Prorocentrum lima clone PL021117001. ${ }^{10}$ In this paper, we report the structure elucidation of prorocentin (1), which possesses the functional groups, all-trans trienes, an epoxide, and the tricyclic ether rings, of the proposed cyclization mechanism for marine polyether toxins. In addition, the possible biosynthesis pathways of its tricyclic ether ring moiety are proposed.

The methylene chloride extracts of lab-cultured P. lima were fractionated by a series of chromatography and RPHPLC. ${ }^{11}$ Prorocentin (1, $3 \mathrm{mg}$ ), an amorphous solid had $[\alpha]^{25} \mathrm{D}-12.7^{\circ}(c 0.2, \mathrm{MeOH}), \mathrm{UV}_{\max }(\mathrm{MeOH}) 274 \mathrm{~nm}(\epsilon$ 25300 ), and IR $v_{\max }(\mathrm{KBr}) 3426,2924,1438,1058,1027$ $\mathrm{cm}^{-1}$. HR-FTMS and the total number of carbons determined by ${ }^{13} \mathrm{C}$ NMR spectra, measured in $\mathrm{CDCl}_{3}$ and $\mathrm{CD}_{3} \mathrm{OD}$, suggested a possible molecule of $\mathrm{C}_{39} \mathrm{H}_{60} \mathrm{O}_{9}$ (observed [M + $\mathrm{Na}]^{+}, m / z$ 695.4137; calcd for $[\mathrm{M}+\mathrm{Na}]^{+}, m / z$ 695.4135), which may contain 10 sites of unsaturation. The resonances of seven olefinic methines $(\delta 122.2,123.9,128.3,129.2$, $129.7,130.2,135.4)$ and three olefinic quateric carbons $(\delta$ $133.8,135.4,137.7)$ in the ${ }^{13} \mathrm{C}$ spectrum $\left(\mathrm{CDCl}_{3}\right)$ accounted for 5 of the 10 sites of unsaturation. The remaining five sites of unsaturation had to be accounted for by ring structures. Since HSQC and DEPTs data showed that 56 of the 60 hydrogen atoms were attached to carbons (5 methyl groups, 11 methylenes, 19 methines), there should be 4 hydroxyl groups in $\mathbf{1}$.

The proton connectivities were elucidated by detailed analysis of two-dimensional NMR experiments, including ${ }^{1} \mathrm{H}-{ }^{1} \mathrm{H}$ COSY, HSQC, HMBC, and NOESY. Long-range ${ }^{4} J_{\mathrm{H}-\mathrm{H}}$ couplings via $\mathrm{sp}^{2}$ carbons such as $\mathrm{H}-5 / \mathrm{H}_{3}-39, \mathrm{H}-23 /$ $\mathrm{H}_{2}-25, \mathrm{H}-23 / \mathrm{H}_{3}-37, \mathrm{H}-33 / \mathrm{H}_{3}-35$, and $\mathrm{H}-33 / \mathrm{H}_{3}-36$ were clearly indicated by cross-peaks. Four partial structures (I, C1-C6; II, C7-C15; III, C16-C21; IV, C23-C36) were obtained as shown in Figure 1. The absence of coupling between $\mathrm{H}-15(\delta 3.55)$ and $\mathrm{H}-16(\delta 3.80)$ was caused by a dihedral angle near $90^{\circ}$. The connectivity between $\mathrm{C} 15$ and $\mathrm{C} 16$ was further deduced from the NOESY cross-peak. The terminal quaternary carbons (C6, C22, C24, and C34) were linked to the fragments via HMBC correlations (Figure 1). According to the data above, the whole carbon backbone was able to be assembled, leaving the position of hydroxyl groups and ether linkages to be determined. The deuteriuminduced upfield ${ }^{13} \mathrm{C}$ chemical shift was observed upon

(10) Dinoflagellate $P$. lima PL021117001 was isolated from the northern coast of Taiwan in 2002 and cultured in seawater enriched with K nutrient at $25^{\circ} \mathrm{C}$ with an $8 / 16$ dark/light photoperoid cycle for 4 weeks.

(11) Algal cells $\left(8.3 \times 10^{9}\right.$ cells $)$, harvested from $450 \mathrm{~L}$ of the cultures, were extracted exhaustively with methanol. Purification of the $\mathrm{CH}_{2} \mathrm{Cl}_{2}$ solubles by successive chromatography with the silica gel $60\left(9: 1 \mathrm{CH}_{2} \mathrm{Cl}_{2}\right)$ $\mathrm{MeOH}$ ), Sephdex LH-20 (MeOH), and HPLC (Biosil Pro-ODS 5U, 55\% $\mathrm{CH}_{3} \mathrm{CN} / \mathrm{H}_{2} \mathrm{O}$ ) gave $3 \mathrm{mg}$ of pure prorocentin.

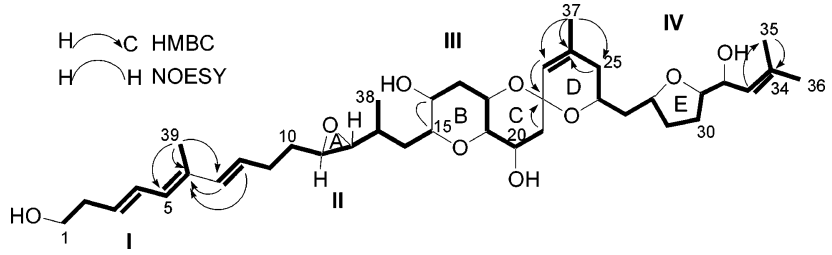

Figure 1. Connectivities established by ${ }^{1} \mathrm{H}-{ }^{1} \mathrm{H}$ COSY, HSQC, HMBC, and NOESY. Heavy lines indicate the connectivities assigned on the basis of ${ }^{1} \mathrm{H}-{ }^{1} \mathrm{H}$ COSY and HSQC. Arrows denote the correlations between protons (tail) and carbons (head) around the quaternary carbons observed in the HMBC. The arc $(\mathrm{H}-15 / \mathrm{H}-$ 16) denoted the correlation of NOESY.

replacing the NMR solvent with $\mathrm{CD}_{3} \mathrm{OD}$ (originally $\mathrm{CD}_{3-}$ $\mathrm{OH})$, resulting in the identification of hydroxyl-bearing carbons. ${ }^{12}$ Significant shifts $(0.09-0.12 \mathrm{ppm})$ were observed for $\mathrm{C} 1, \mathrm{C} 16, \mathrm{C} 20$, and $\mathrm{C} 32$, while the remaining nine signals were superimposed on each other within $0.03 \mathrm{ppm}$. These oxycarbons were arranged to form an epoxide, a furan and three pyran rings. Therefore, a planar structure of $\mathbf{1}$ was elucidated. A summary of the assignments of all the protons and carbons mentioned above are shown in Table 1 (see also Supporting Information Table S1).

Table 1. ${ }^{1} \mathrm{H}$ NMR and ${ }^{13} \mathrm{C}$ NMR Data of $\mathbf{1}\left(\mathrm{CDCl}_{3}\right)^{a}$

\begin{tabular}{|c|c|c|c|c|c|}
\hline No. & $\delta_{\mathrm{C}}$ (mult.) & $\delta_{\mathrm{H}}($ mult. $J$ in $\mathrm{Hz})$ & No. & $\delta_{C}$ (mult.) & $\delta_{\mathrm{H}}($ mult. $J$ in $\mathrm{Hz})$ \\
\hline 1 & $62.0(\mathrm{t})$ & $3.66(\mathrm{t}, 6.2)$ & $\begin{array}{l}\mathbf{2 1}_{\mathrm{ax}} \\
21_{\mathrm{eq}}\end{array}$ & $40.0(\mathrm{t})$ & $\begin{array}{l}1.76(\mathrm{~m}) \\
2.05(\mathrm{dd}, 14.3,3.4)\end{array}$ \\
\hline 2 & $36.6(t)$ & $2.38(\mathrm{q}, 6.4)$ & 22 & $96.2(\mathrm{~s})$ & \\
\hline 3 & $130.2(\mathrm{~d})$ & $5.65(\mathrm{~m})$ & 23 & $122.2(\mathrm{~d})$ & $5.27(\mathrm{~s})$ \\
\hline 4 & $129.7(d)$ & $6.44(\mathrm{dd}, 15.1,11.1)$ & 24 & $137.7(\mathrm{~s})$ & \\
\hline 5 & $129.2(\mathrm{~d})$ & $5.96(\mathrm{~d}, 11.1)$ & $\begin{array}{l}25_{\mathrm{ax}} \\
25_{\mathrm{eq}}\end{array}$ & $35.2(\mathrm{t})$ & $\begin{array}{l}1.79(\mathrm{~m}) \\
1.97(\mathrm{~m})\end{array}$ \\
\hline 6 & $133.8(\mathrm{~s})$ & & $26_{a x}$ & $68.1(d)$ & $4.01(\mathrm{~m})$ \\
\hline 7 & $135.4(d)$ & $6.10(\mathrm{~d}, 15.5)$ & 27 & $40.8(t)$ & $1.75(\mathrm{~m})$ \\
\hline 8 & $128.3(d)$ & $5.56(\mathrm{~m})$ & 28 & 79.5 (d) & $4.06(\mathrm{~m})$ \\
\hline 9 & $29.3(\mathrm{t})$ & $2.25(\mathrm{~m})$ & $\begin{array}{l}29_{a} \\
29_{b}\end{array}$ & $33.8(\mathrm{t})$ & $\begin{array}{l}1.49(\mathrm{~m}) \\
1.98(\mathrm{~m})\end{array}$ \\
\hline 10 & $32.2(\mathrm{t})$ & $1.62(\mathrm{~m})$ & $\begin{array}{l}30_{a} \\
30_{b}\end{array}$ & $28.5(\mathrm{t})$ & $\begin{array}{l}1.34(\mathrm{~m}) \\
1.81(\mathrm{~m})\end{array}$ \\
\hline 11 & $57.8(d)$ & $2.72(\mathrm{td}, 5.6,2.1)$ & 31 & $85.5(d)$ & $3.93(\mathrm{dt}, 7.0,8.4)$ \\
\hline 12 & 63.2 (d) & $2.46(\mathrm{dd}, 7.0,2.1)$ & 32 & $72.1(\mathrm{~d})$ & $4.10(\mathrm{dd}, 7.0,8.9)$ \\
\hline 13 & 32.2 (d) & $1.62(\mathrm{~m})$ & 33 & $123.9(\mathrm{~d})$ & $5.02(\mathrm{~d}, 8.9)$ \\
\hline $\begin{array}{l}14_{a} \\
14_{b}\end{array}$ & $39.2(\mathrm{t})$ & $\begin{array}{l}1.42(\mathrm{~m}) \\
1.65(\mathrm{~m})\end{array}$ & 34 & $135.4(\mathrm{~s})$ & \\
\hline $15_{\mathrm{ax}}$ & $73.6(d)$ & $3.55(\mathrm{~m})$ & 35 & $18.9(q)$ & $1.70(\mathrm{~s})$ \\
\hline $16_{\text {eq }}$ & $70.5(d)$ & $3.80(\mathrm{~m})$ & 36 & $25.9(\mathrm{q})$ & $1.69(\mathrm{~s})$ \\
\hline $\begin{array}{l}17_{\mathrm{ax}} \\
17_{\mathrm{eq}}\end{array}$ & $39.4(t)$ & $\begin{array}{l}1.41(\mathrm{~m}) \\
2.00(\mathrm{~m})\end{array}$ & 37 & $22.8(q)$ & $1.71(\mathrm{~s})$ \\
\hline $18_{\mathrm{ax}}$ & 70.9 (d) & $3.81(\mathrm{~m})$ & 38 & $17.5(\mathrm{q})$ & $0.92(\mathrm{~d}, 6.4)$ \\
\hline $\begin{array}{l}19_{\mathrm{ax}} \\
20_{\mathrm{eq}}\end{array}$ & $\begin{array}{l}76.1(\mathrm{~d}) \\
66.4(\mathrm{~d})\end{array}$ & $\begin{array}{l}3.00(\mathrm{dd}, 2.9,9.3) \\
4.02(\mathrm{~m})\end{array}$ & 39 & $12.8(q)$ & $1.81(\mathrm{~s})$ \\
\hline
\end{tabular}

${ }^{a}$ Reference to residual solvent $\mathrm{CDCl}_{3}$ signals at $\delta_{\mathrm{H}} 7.24$ and $\delta^{13} \mathrm{C} 77.0$ and measured at $25{ }^{\circ} \mathrm{C}, 500 \mathrm{MHz}$ for ${ }^{1} \mathrm{H}$, and $125 \mathrm{MHz}$ for ${ }^{13} \mathrm{C}$. ${ }^{13} \mathrm{C}$ multiplicities were assigned from DEPT experiments.

The proposed structure was further supported by positive ion ESI Q-TOF tandem mass studies (Supporting Information). An electron spray ionization MS/MS experiment was

(12) Pfeffer, P. E.; Valentine, K. M.; Parrish, F. W. J. Am. Chem. Soc 1979, 101, 1265-1274. 
carried out using ions with positive charge (cations), and $[\mathrm{M}+\mathrm{Na}]^{+}$ion $(\mathrm{m} / \mathrm{z}, 695.5)$ was chosen as a precursor ion. The prominent product ions at $\mathrm{m} / \mathrm{z} 497,301$, and 221 confirmed the structure of 6/6/6-trans-fused/spiro-linked tricyclic ethers. ${ }^{13}$

The relative stereochemistry of the tricyclic ether rings $(\mathrm{C} 15-\mathrm{C} 26)$ and the tetrahydrofuran ring $(\mathrm{C} 28-\mathrm{C} 31)$ were deduced from NOESY correlations and ${ }^{1} \mathrm{H}-{ }^{1} \mathrm{H}$ coupling constants as shown in Figure 2. The typical axial-axial

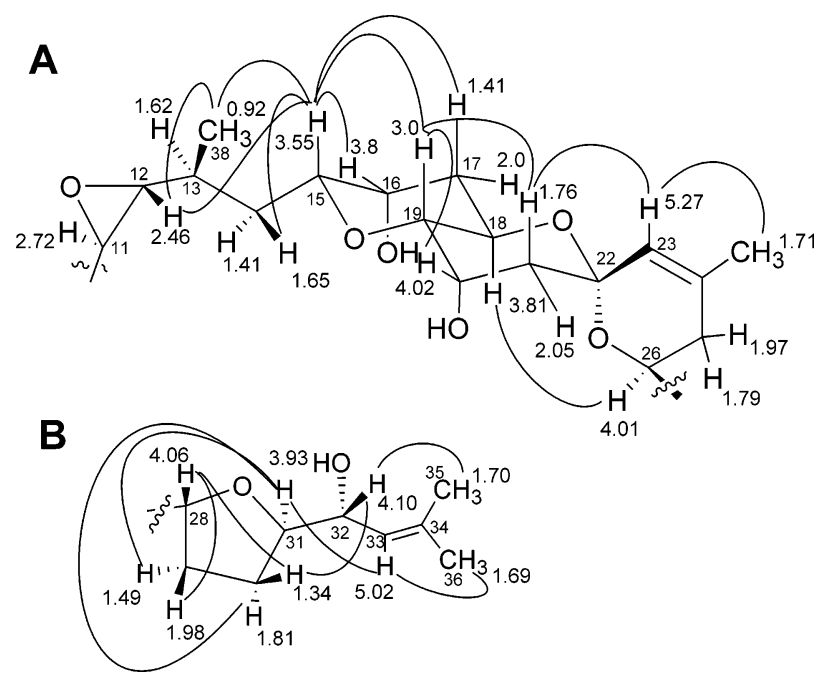

Figure 2. Relative stereochemistry of substructures A (C15-C26) and $\mathrm{B}(\mathrm{C} 28-\mathrm{C} 36)$ in $\mathbf{1}$. The arc shows NOESY correlations.

coupling constant of $9.3 \mathrm{~Hz}$ between $\mathrm{H}-18_{\mathrm{ax}}$ and $\mathrm{H}-19_{\mathrm{ax}}{ }^{14}$ and NOEs, H-15 $5_{\mathrm{ax}} / \mathrm{H}-16_{\mathrm{eq}}, \mathrm{H}-15_{\mathrm{ax}} / \mathrm{H}-17_{\mathrm{ax}}, \mathrm{H}-19_{\mathrm{ax}} / \mathrm{H}-15_{\mathrm{ax}}$, $\mathrm{H}-19_{\mathrm{ax}} / \mathrm{H}-17_{\mathrm{ax}}, \mathrm{H}-19_{\mathrm{ax}} / \mathrm{H}-20_{\mathrm{eq}}, \mathrm{H}-19_{\mathrm{ax}} / \mathrm{H}-21_{\mathrm{ax}}$, demonstrated that the $\mathrm{B} / \mathrm{C}$ rings were both chair conformations and transfused. In addition, the small coupling constants observed between $\mathrm{H}-16_{\mathrm{eq}} / \mathrm{H}-15_{\mathrm{ax}}$ and between $\mathrm{H}-20_{\mathrm{eq}} / \mathrm{H}-19_{\mathrm{ax}}$ indicated axial orientations for both $16-\mathrm{OH}$ and $20-\mathrm{OH}$. The NOESY spectrum gave strong NOE cross-peaks for $\mathrm{H}-18_{\mathrm{ax}} / \mathrm{H}-26_{\mathrm{ax}}$ and $\mathrm{H}-21_{\mathrm{ax}} / \mathrm{H}-23$ defined the relative configuration at the spiroketal carbon (C22). The cross-peaks of $\mathrm{H}_{3}-38 / \mathrm{H}-12, \mathrm{H}_{3^{-}}$ 38/H-15, H-12/H-15, and H14 $/$ H15 in NOESY contributed to the relative configuration of the $\mathrm{C} 12$ to $\mathrm{C} 15$ carbon chain (Figure 2A). The lack of NOE between $\mathrm{H}-28 / \mathrm{H}-31$ was indicative of the anti arrangement for $\mathrm{H}-28$ to $\mathrm{H}-31$ in the tetrahydrofuran ring. This anti-oriented configuration was further proved by the clear NOE cross-peaks of $\mathrm{H}-28 / \mathrm{H}-$ $29_{\mathrm{b}}, \mathrm{H}-28 / \mathrm{H}-30_{\mathrm{a}}, \mathrm{H}-31 / \mathrm{H}-29_{\mathrm{a}}$, and H-31/H-30 . The coupling constants of $\mathrm{H}-31 / \mathrm{H}-32(7.0 \mathrm{~Hz})$ and $\mathrm{H}-32 / \mathrm{H}-33(8.9 \mathrm{~Hz})$,

(13) These bond cleavages at the sites characteristic of ether rings were reported on dinoflagellate toxins of ciguatoxins (Yasumoto, T.; Igarashi, T.; Legrand, A.-M.; Cruchet, P.; Chinain, M.; Fujita, T.; Naoki, H. J. Am. Chem. Soc. 2000, 122, 4988-4989), yessotoxin (Naoki, H.; Murata, M.; Yasumoto, T. Rapid Comm. Mass Spectrom. 1993, 7, 179-182), and amphidinol (Satake, M.; Murata, M.; Fujita, T.; Naoki, H.; Yasumoto, T. J. Am. Chem. Soc. 1991, 113, 9859-9861).

(14) Coupling constants of anguar protons in the case of brevetoxins and ciguatoxin (Murata, M.; Legarand, A. M.; Ishibashi, Y.; Fukui, M.; Yasumoto, T. J. Am. Chem. Soc. 1990, 112, 4380-4386) were ca. 9 Hz. and NOEs, $\mathrm{H}-31 / \mathrm{H} 33, \mathrm{H}-33 / \mathrm{H}_{3}-36, \mathrm{H}-32 / \mathrm{H}-30_{\mathrm{a}}$, and $\mathrm{H}-32 /$ $\mathrm{H}_{3}-35$, indicated rotational constraints along the $\mathrm{C} 31-\mathrm{C} 32$ and $\mathrm{C} 32-\mathrm{C} 33$ bonds, allowing us to interrelate the relative configuration of $\mathrm{C} 31$ to $\mathrm{C} 36$ (Figure 2B). The epoxide ring at $\mathrm{C} 11-\mathrm{C} 12$ was elucidated as trans by proton-proton coupling constant $\left(J_{11,12}=2.1 \mathrm{~Hz}\right){ }^{15}$ The $\Delta^{3,4}, \Delta^{5,6}$, and $\Delta^{7,8}$ olefins were indicated to have all $(E)$-geometries on the basis of NOESY data $\left(\mathrm{H}_{2}-2 / \mathrm{H}-4, \mathrm{H}-4 / \mathrm{H}_{3}-39, \mathrm{H}-8 / \mathrm{H}_{3}-39, \mathrm{H}-3 / \mathrm{H}-\right.$ 5, and $\mathrm{H}-5 / \mathrm{H}-7)$ and the ${ }^{1} \mathrm{H}-{ }^{1} \mathrm{H}$ coupling constants $\left(J_{3,4}=\right.$ $15.1 \mathrm{~Hz}$, and $J_{7,8}=15.5 \mathrm{~Hz}$ ). All the data above allowed us to assign the relative stereostructure of $\mathbf{1}$.

Prorocentin, a C35 polyketide chain with four pendant methyl groups, possessed an all-trans triene moiety, an epoxide, a furan ring, and the 6/6/6-trans-fused/spiro-linked tricyclic ether rings. This new marine dinoflagellate polyketide supported the proposed cyclization mechanism, polyene formation, epoxidation, and cyclization, of marine polyether toxins such as okadaic acid and brevetoxins. Both $\mathbf{1}$ and okadaic acid found in the PL021117001 strain of P. lima suggested that they might share part of their biosynthetic pathway. The fact that both spiro-linked ethers (C/D rings) of $\mathbf{1}$ and okadaic acid ${ }^{16}$ (A/B rings) shared the same backbone might be explained by a plausible biosynthetic pathway as shown in Scheme 1A. An alternative route (Scheme 1B) was

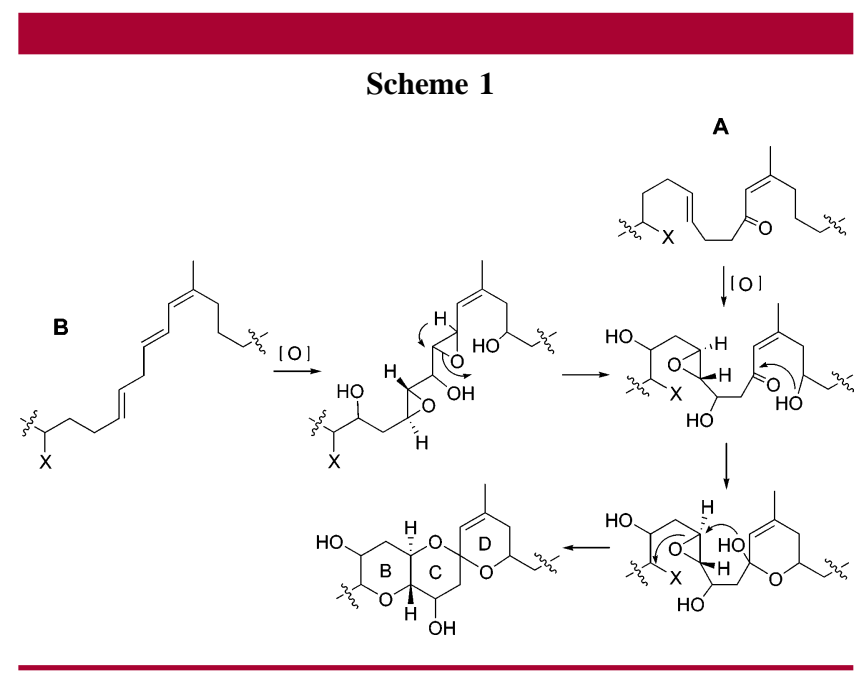

proposed according to the conjugated dienes moiety in $\mathbf{1}$. Toward further disclosure of this polyketide biosynthesis, labeling experiments are currently under the way. Prorocentin (1) exhibited inhibitory activity against human colon adenocarcinoma DLD-1 and human malignant melanoma RPMI7951 with $\mathrm{IC}_{50}$ values of 16.7 and $83.6 \mu \mathrm{g} / \mathrm{mL}$, respectively. The antimicrobial activity against Staphylococcus aureus BRBC 12154 was negative at a dose of $100 \mu \mathrm{g} / \mathrm{mL}$.

(15) (a) Kobayashi, J.; Kubota, T.; Takahashi, M.; Ishibashi, M.; Tsuda M.; Naoki H. J. Org. Chem. 1999, 64, 1478-1482. (b) Kobayashi, J.; Ishibashi, M.; Nakamura H.; Ohizumi, Y.; Yamasu, T.; Sasaki, T.; Hirata, Y. Tetrahedron Lett. 1986, 27, 5755-5758.

(16) The high incorporation ratio at $\mathrm{O}(4)$, the oxygen atom of the $\mathrm{A}$ ring in okadaic acid, from $\left[{ }^{18} \mathrm{O}_{2}\right]$ acetate has been reported: Murata, M.; Izumikawa, M.; Tachibana, K.; Fujita, T.; Naoki, H. J. Am. Chem. Soc. 1998, 120, 147-151. Needham, J.; Hu, T.; McLachlan, J. L. J. Chem. Soc., Chem. Commun. 1995, 1623-1624. 
Acknowledgment. Financial support of this project was provided by grants for basic scientific research (NSC922113-M-038-002 and NSC93-2323-B-002) from the National Science Council of Taiwan. NMR and FTMS spectra were obtained at the Instrument Centers of National Taiwan University and National Sun Yet-Sen University, respectively. The assistance of the Mrs. Shoou-ling Huang and Mrs. Shiu-CHing Yu is gratefully appreciated. We are also grateful to Taiwan Micromass, Ltd., for their technical assistance.

Supporting Information Available: Experimental details, as well as one- and two-dimensional NMR and Q-TOF MS/MS data for prorocentin. This material is available free of charge via the Internet at http://pubs.acs.org.

OL051300U 